\title{
負の相関ルールを抽出する高速トップダウン型ア ルゴリズム
}

\section{An Efficient Top-Down Mining of Negative Association Rules}

\author{
$\underset{\text { Ide Noriko }}{\text { 井子 }}$ \\ 山梨大学大学院 医学工学総合教育部 コンピュータ・メディア工学専攻 \\ Computer Science and Media Engineering, Interdisciplinary Graduate School of Medical and Engineering, University of Yamanashi

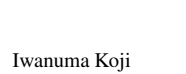 \\ 山梨大学大学院 医学工学総合研究部 コンピュータ・メディア工学専攻
Interdisciplinary Graduate School of Medical and Engineering, University of Yamanashi
iwanuma@yamanashi.ac.jp \\ 山本 泰生（同上) \\ Yamamoto Yoshitaka yyamamoto@yamanashi.ac.jp
}

keywords: negative association rule, mining, top-down search, suffix tree

\begin{abstract}
Summary
Negative association rules represent some relationships between presence and absence of itemsets. In general, the number of negative association rules is enormously huge even if compared with that of positive association rules. Therefore, an efficient mining method is quite important. In this paper, we propose a novel top-down mining method for negative association rules in the forms of $X \Rightarrow \neg Y$ and $\neg X \Rightarrow Y$. The proposed method search a suffix tree over frequent itemsets in a top-down manner, and efficiently extract all of valid negative rules of these two types, step by step. The suffix tree plays very important roles for effectively pruning a lot of redundant searches such as the one producing non-minimal valid negative rules. We also show some good results of experiments for evaluating our proposed method. The proposed method is given for simple negative rule mining based on the support and confidence measures, therefore is definitely the most fundamental and important framework, into which additional measures can be easily introduced if necessary.
\end{abstract}

\section{1.は じめに}

本論文では, データベース中の有用な負の相関ルール を完全かつ効果的に抽出することを目的として,トップ ダウン型の負ルール抽出アルゴリズムを提案する . また 提案アルゴリズムを実装し実証評価を行った結果，良好 な結果を得たので報告する.

正の相関ルール [AS 94, HPY00] とは, 頻繁に共起する 事象の関係を記述したものであり, $X \Rightarrow Y$ のような形式 のルールとなる . 一方, 本研究で扱う負の相関ルールは, ある事象が発生した際に別の事象が“生起しない”現象を 記述するものであり， $\neg \Rightarrow Y, X \Rightarrow \neg Y, \neg X \Rightarrow \neg Y$ と いう形のルールとして記述される . これは実用上大変重要 であり，1990 年代末から研究 [AY 98, BMS97, SON98] が行われてきた.

一般に, 負の相関ルールは非常に多数存在し, 正ル一 ルと比較しても，光の数は格段に多い，光のため，有用な 負ルールを絞り込むための評価尺度についての研究 [AY 98, AZ04, BMS97, SON98, YBYZ02] が多く成されてい る . 一方で，負の相関ルールの効率的で高速な抽出計算
法はあまり研究されてこなかった . 先行研究 [WZZ04, CYZC06, ZY07] では, Apriori 流 [AS 94] のボトムアッ プ型の抽出計算法を提案している .この手法は負の相関 ルールの膨大な台集合を明示的に生成してルール抽出を 行っており，非常に効率が悪い．これに対して [WZC08] では, 頻出アイテム集合の組合せから負の相関ルールを抽 出し, 負ルールの台集合の明示的な生成を避けている.し かし, やはりボトムアップ型の計算法を採用しており, 負 ルールの相互関係の検査が難しいために計算効率は低い .

3 種類の負ルールのうち, 両否定形のルール $X \Rightarrow \neg Y$ は支持度と確信度による選別機構が有効に働かない．ま た，前件 $\neg X$ と後件 $\neg Y$ の間の統計的関係性を見出す ことも一般にはかなり難しく, 両否定形の負ルールの有 効性は低いと考えられる. 光こで本論文では左右の否定 形 , 即ち $\neg X \Rightarrow Y$ と $X \Rightarrow \neg Y$ の形の負ルールに焦点を 絞り，ルール抽出計算の高速化を考察する . 具体的には， 効率的なトップダウン型の抽出計算法を新たに提案する. 提案手法では，頻出アイテム集合を接尾木上に保持し， トップダウン型の探索を行い, 左右の否定形ルールの間 
の関係を効率的に検査する .これにより探索の枝刈を効 果的に実行し，負ルール抽出計算の高速化を図る。提案 アルゴリズムの正当性を理論的に示すと同時に, 試験的 に実装したシステムを用いた性能評価実験の結果を報告 する .

本論文では, 負ルールの評価度は支持度と確信度だけ を考慮して負ルールの抽出法を考えるが , これは他の評 価尺度を加えていく上での基盤であり，弚の高速計算法 の開発は極めて重要な試みである.

論文の構成は以下の通りである. 第 2 章は前準備であ る. 第 3 章では先行研究と本論文で扱う負の相関ルール の定義と性質について述べる. 第 4 章で先行研究の問題 点と, 弚の解決策としての接尾木を用いた負の相関ルー ルのトップダウン型抽出アルゴリズムを示す . また正当 性について理論的に証明する. 第 5 章で実証実験の結果 と考察を示す.第 6 章はまとめである.

\section{2. 準備}

$I=\left\{a_{1}, a_{2}, \ldots, a_{n}\right\}$ をアイテムの全体集合とするとき， トランザクション $t$ をアイテムの集合 $t \subseteq I$ と定める . ト ランザクションデータベース $D$ をトランザクションの多 重集合 ${ }^{2}$ とする.$X$ をアイテム集合とするとき,$X \subseteq t$ となる $D$ 中のトランザクション $t$ を出現と呼び, 弚の出 現の集合を $D(X)$ と略記する . 集合 $A$ の大きさ (濃度) を $|A|$ と表記するものとし， $X$ の $D$ 中の支持度 $\sup (X)$ を, $\sup (X)=\frac{|D(X)|}{|D|}$ と定義する.

正の相関ルール (以下, 適宜 “正ルール”と略記) を $X \cap$ $Y=\emptyset$ であるアイテム集合 $X, Y$ からなる表現 $X \Rightarrow Y$ と

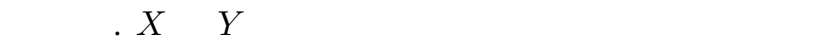
$X \cup Y$ を台集合 (underlying set) と呼ぶ . 正ルールに対 する支持度 sup と確信度 conf を以下のように定義する．

$\sup (X \Rightarrow Y)=\sup (X \cup Y), \quad \operatorname{conf}(X \Rightarrow Y)=\frac{\sup (X \cup Y)}{\sup (X)}$

最小支持度 $m s$ と最小確信度 $m c$ とはユーザか支持度と確 信度に関して与える閾値である. $\sup (X) \geq m s$ を満たす $X$ を頻出アイテム集合と呼ぶ . また $\sup (X \Rightarrow Y) \geq m s$ と $\operatorname{conf}(X \Rightarrow Y) \geq m c$ の両方を満たす $X \Rightarrow Y$ を有効 (valid) な正の相関ルールと呼ぶ .

\section{3. 負の相関ルール}

本論文では , 負の相関ルール (negative association rule: 以下では適宜 “負ルール”と略記する) を考察する.$X$ と $Y$ を $X \cap Y=\emptyset$ であるアイテム集合とするとき，負ルー ルとは以下のいずれかの表現である .

$X \Rightarrow \neg Y \quad$ (右否定形もしくは後件負形),

$\neg X \Rightarrow Y \quad$ (左否定形もしくは前件負形),

$* 2$ と定義し, 以下では適宜, データベースと略記する . データ ベースには同一のトランザクション (アイテム集合) が複数含 まれてもよいとする.必要ならば ID 番号等で識別する.

\section{$\neg X \Rightarrow \neg Y \quad$ (両否定形)}

上記の $\neg X$ はアイテム集合の否定表現であり，負アイ テム集合と呼ぶ . 否定表現の解釈は一般に難しく，負の 相関ルールにおいても，解棌は大きく2つに分かれてい る [CYZC06] . 1 つはアイテム集合内のアイテムの関係 を論理和と考えるもの [AZ04, AY 98, BMS97, THC02, TRLD08] である. これは $X \Rightarrow \neg\{a, b\}$ を $X \Rightarrow \neg(a \vee b)$ と解釈するもので,「トランザクションに $X$ が出現する 場合, アイテム $a, b$ はどちらも現れないことが多い」を表 している.$X \Rightarrow(\neg a \wedge \neg b)$ と変形できるので, 以下では 否定積形と呼ぶ．もう 1 つの解釈は論理積で解釈するも の [CYZC06, SON98, WZC08, WZZ04, YBYZ02, ZY07] である. 即ち, $X \Rightarrow \neg\{a, b\}$ を $X \Rightarrow \neg(a \wedge b)$ と解釈する もので, $\ulcorner X$ が出現する場合, $a, b$ のどちらか一方は出現 しないことが多い」を表している. $X \Rightarrow(\neg a \vee \neg b)$ と変 形できるので, 以下では否定和形と呼ぶ . 否定和形の負 ルールの支持度は，下記に示すように正のアイテム集合 の支持度を基に計算でき，正の相関ルールマイニングで 開発された技術を比較的容易に転用できる．またアイテ ム集合 $I$ を固定したときに, 可能な負ルールの数も否定 和形の方が大幅に少ない [CYZC06] ことが知られている. このような事情から近年では否定和形に関する研究が多 くなされている．本論文では否定和形の負ルールに関す る効率的な抽出計算を考察する.

負ルールの支持度と確信度を文献 [WZZ04] に従って 定める. 以下では $C_{X}$ でアイテム集合 $X$ または負アイ テム集合 $\neg X$ のどちらかを表すものと約束する .

【定義 1】（[WZZ04]）負アイテム集合および負ルール の支持度 sup と確信度 conf を以下のように定める.

$$
\begin{aligned}
\sup (\neg X) & =1-\sup (X) \\
\sup (X \Rightarrow \neg Y) & =\sup (X)-\sup (X \cup Y) \\
\sup (\neg X \Rightarrow Y) & =\sup (Y)-\sup (X \cup Y) \\
\sup (\neg X \Rightarrow \neg Y) & =1-\sup (X)-\sup (Y)+\sup (X \cup Y) \\
\operatorname{conf}\left(C_{X} \Rightarrow C_{Y}\right) & =\frac{\sup \left(C_{X} \Rightarrow C_{Y}\right)}{\sup \left(C_{X}\right)}
\end{aligned}
$$

相関ルールの発見問題とは, 支持度や確信度のような 評価尺度と光の閾値が与えられたときに，閾値を超える 有効なルールをデータベースから全て抽出する計算問題 である.負ルールは正ルールと比較しても，光の数か格段 に多い, 㚇のため, これまでは負ルールを絞り込むためのの (支持度と確信度に続く) 新しい評価尺度か数多く研究さ れてきた [AY 98, AZ04, BMS97, SON98, YBYZ02] . 支 持度と確信度に基づく負ルールの抽出計算は, 種々の負 ルールの抽出計算の最も重要な基盤であるが, 谷の研究 はあまり行われてきていない，次節ではまず，有効な負 ルールの概念定義に関する先行研究の問題点を述べ, 光 の解決策について考察する. 


\section{$3 \cdot 1$ 先行研究と問題点}

負の相関ルールの効率的な抽出計算に関する先駆的な 研究として [WZZ04] がある.弚こでは支持度と確信度 に加えて , 以下の興味度 (interest) ${ }^{* 3}$ 用いて負ルールの 評価と絞り込みを試みている。

$$
\operatorname{inter}(X, Y)=|\sup (X \cup Y)-\sup (X) \cdot \sup (Y)|
$$

興味度は $X$ と $Y$ の独立性を示す尺度で, Lift などの多 くの類似の尺度 [TKS02] がある . [WZZ04] では，支持 度，確信度および興味度を用いて，正負の有効 (valid)な 相関ルール $C_{X} \Rightarrow C_{Y}$ を以下のように定義している.

【定義 2】（[WZZ04]）支持度, 確信度, 興味度の閾値 を产れ枈れ $m s, m c, m i$ とするとき，以下の条件を満た す $C_{X} \Rightarrow C_{Y}$ を $\mathbf{S C I}$-有効な相関ルールと定める.

(1) $X \cap Y=\emptyset^{* 4}$

(2) $\sup (X) \geq m s$ かつ $\sup (Y) \geq m s$

(3) $\sup \left(C_{X} \Rightarrow C_{Y}\right) \geq m s$

(4) $\operatorname{conf}\left(C_{X} \Rightarrow C_{Y}\right) \geq m c$

(5) $\operatorname{inter}\left(C_{X}, C_{Y}\right) \geq m i$

この定義の下で , [WZZ04] では Apriori 準拠アルゴリ ズムを開発し，SCI-有効な正および負のルールの同時抽 出を試みている。確信度と興味度は逆単調性を満たさな いので, ルールの生成過程でこの 2 つの尺度を用いて不 用意に枝刈をすると，アルゴリズムの完全性が失われて しまう . [CYZC06]ではこの点を指摘し , [WZZ04] の提 案アルゴリズムが不完全であることを明らかにしている . この問題の解決を目指して , [CYZC06, WZC08]では興 味度ではなく，極小性 ${ }^{*}$ に基づく探索空間の枝刈手法を 考察している.以下に [WZC08] の右極小性の定義を示 す．まず負ルールがSC-有効であることを，定義 2 の (1) から (4) の条件を満たす場合と定める .

【定義 3】（[WZC08]）以下の 2 つの条件を満たす右 否定形 $C_{X} \Rightarrow \neg Y$ を右極小な負ルールと呼ぶ.

(1) $C_{X} \Rightarrow \neg Y$ は SC-有効である .

(2) $Y$ の真部分集合 $Y^{\prime}$ で, $C_{X} \Rightarrow \neg Y^{\prime}$ が $\mathrm{SC}$-有効と なるものは存在しない .

〈命題 1〉（右単調性 [WZC08]） $Y \subset Y^{\prime}$ に対して以下 が成り立つ。

(1) $\sup \left(C_{X} \Rightarrow \neg Y^{\prime}\right) \geq \sup \left(C_{X} \Rightarrow \neg Y\right)$

(2) $\operatorname{conf}\left(C_{X} \Rightarrow \neg Y^{\prime}\right) \geq \operatorname{conf}\left(C_{X} \Rightarrow \neg Y\right)$

[ 補題 1]（ SC-有効性の右単調性）右否定形 $C_{X} \Rightarrow \neg Y$ がSC-有効ならば， $Y \subset Y^{\prime}$ なる頻出アイテム集合 $Y^{\prime}$ に 関して,$C_{X} \Rightarrow \neg Y^{\prime}$ も必ず SC-有効である。

《証明》命題 1 と SC-有効性の定義より明らか.

*3 この興味度は PS (Piatetsky-Shapiro) 尺度と呼ばれる場合 (例 えば [TKS02]) が多い .

*4 本論文では, この条件を非重複性条件と呼ぶ。

*5[CYZC06] の極小性の定義は，確信度を考慮せずに支持度だ けの極小性 , 即ち定義 2 の (1) から (3) を満たす極小なルール を考えており, 確信度の充足性に関して問題が生じる。
補題 1 より,右極小でない右否定ルールはて長と考えら れる.以上から [WZC08]では, 右否定形は右極小な SC有効な負ルールだけに限定して抽出計算を行っている .

\section{$3 \cdot 2$ 無矛盾性を考慮した負の相関ルール}

本論文では，SC-有効性に更に無矛盾性 (consistency) 条件を追加した SCC-有効性を新たに提案する。

【定義 4】（SCC-有効性, 右極小性）支持度，確信度光 れ光れの閾值を $m s, m c$ とし， $X$ と $Y$ をアイテム集合と する. $C_{X} \Rightarrow C_{Y}$ を右否定，左否定，両否定のいずれかの 形の負ルールとするとき，以下の条件を満たす $C_{X} \Rightarrow C_{Y}$ を SCC-有効な負の相関ルールと呼ぶ .

(1) $X \cap Y=\emptyset$

(2) $\sup (X) \geq m s$ かつ $\sup (Y) \geq m s$

(3) $\sup (X \Rightarrow Y)<m s$

(4) $\sup \left(C_{X} \Rightarrow C_{Y}\right) \geq m s$

(5) $\operatorname{conf}\left(C_{X} \Rightarrow C_{Y}\right) \geq m c$

SCC-有効な負ルールの右極小性は, 定義 3 と全く同樣に 定める.

定義 4 は負ルールを対象としており，正ルールについ ては何も言及していない点に注意して頂きたい，定義 4 の条件 (3) は, $C_{X} \Rightarrow C_{Y}$ の骨格となる正ルール $X \Rightarrow Y$ に対する条件であり， $X \Rightarrow Y$ と $X \Rightarrow \neg Y$ が同時に抽出 されるような矛盾を回避するために必要な条件である．以 下では条件 (3) を満たす負ルールを無矛盾 (consistent) と 呼ぶ . 無矛盾性は [WZZ04, CYZC06, WZC08] では全く 考慮されていない*6 .[TRLD08]では，抽出された主ルー ル (例えば, $X \Rightarrow Y)$ に対する例外ルール $(X \Rightarrow \neg Y)$ の同時抽出 ${ }^{* 7}$ を取り扱っているが, 有効な例外ルールの 判別基準を主な考察の対象としており，ファジィ関数の 利用を提案している．筆者らの知る限り，負ルールの無 矛盾性を明示的に考慮するのは，本論文が初めてである． 正ルールに対しては明らかに右逆単調性が成り立つ. 即 ち $Y \subset Y^{\prime}$ に対して, $\sup (X \Rightarrow Y) \geq \sup \left(X \Rightarrow Y^{\prime}\right)$ が成 り立つ.よって命題 1 と併せて以下が成り立つ.

[ 補題 2]（ SCC-有効性の右単調性）右否定形 $C_{X} \Rightarrow$ $\neg Y$ が SCC-有効ならば， $Y \subset Y^{\prime}$ なる頻出アイテム集合 $Y^{\prime}$ に関して,$C_{X} \Rightarrow \neg Y^{\prime}$ も必ず SCC-有効である。

以上から，SCC-有効な右否定形に対しても，右極小性 は妥当な定義となる. 右極小でない SCC-有効な右否定 ルールはて長と考えられ，抽出の対象から取り除く . 一 方で $X \subset X^{\prime}$ なる $X$ と $X^{\prime}$ に対して, $\operatorname{conf}\left(\neg X \Rightarrow C_{Y}\right)$ と $\operatorname{conf}\left(\neg X^{\prime} \Rightarrow C_{Y}\right)$ の大小関係は一般には定まらない . よって左否定形に関しては，極小性に基づくルール抽出

\footnotetext{
*6 [WZZ04] で示されたルール抽出アルゴリズムでは, 暗黙のう ちに，無矛盾な負ルールだけを抽出すようになっている．しか し , 負ルールの有効性の定義では無矛盾性は全く考慮されてい ない . 即ち , 抽出すべき負ルールの仕樣と実際の抽出実行コー ドの間に齟䶣が存在していることに注意して頂きたい .

*7 [TRLD08] では否定積形 $X \Rightarrow \neg a \wedge \neg b$ を扱っており，この 意味でも本論文とは枠組みが異なる．
} 
計算の効率化はできないことに注意して頂きたい .

\section{4. 高速な抽出計算アルゴリズム}

本章では SCC-有効な負ルールの高速抽出法を提案する .

\section{$4 \cdot 1$ 先行手法の問題点とその解決法}

先行研究 [WZZ04, CYZC06, ZY07] では, Apriori 法 [AS 94] に準拠して，正と負の相関ルールを同時並行的に 生成している. まず正負のルールの台集合の集合 $P L$ と $N L$ を光れ光れ生成し，次に $P L$ と $N L$ の各集合を分割し て正と負のルールを生成している．PL は頻出アイテム集 合の集合であり，NL は $P L$ の補集合の集合である .一般 に，NLは $P L$ に比べて非常に大きな集合となり，抽出に は多大な時間がかかる.この解決を目的として, [WZZ04] では $P L$ と $N L$ の生成過程での確信度や興味度による枝刚 りを行ったが, 結果としてアルゴリズムの完全性を失っ ていた [CYZC06] .

有効な負ルール $C_{X} \Rightarrow C_{Y}$ の定義から分かるように， $X$ と $Y$ は頻出アイテム集合であり，NL は本来は必要な い. [WZC08] では負ルールの台集合 $N L$ は生成せずに， $P L$ だけを生成し，PL 中の 2 つの頻出アイテム集合の組 合せから有効な負ルールを生成している．以下では要素 数 $k$ の頻出アイテム集合の集合を FISS $^{k}$ と表記する. ま た以下の負ルールの集合を， $C R(i, j)$ と表記する .

$$
\left\{C_{X} \Rightarrow C_{Y} \mid X \in \mathrm{FISS}^{i}, Y \in \mathrm{FISS}^{j}, \operatorname{Pru}(X, Y)\right\}
$$

但し，Pru(_,_) は適当な枝刈*8を行うための条件式であ る . このとき , [WZC08] の負ルール抽出アルゴリズムの 骨格*9は以下のようになる .

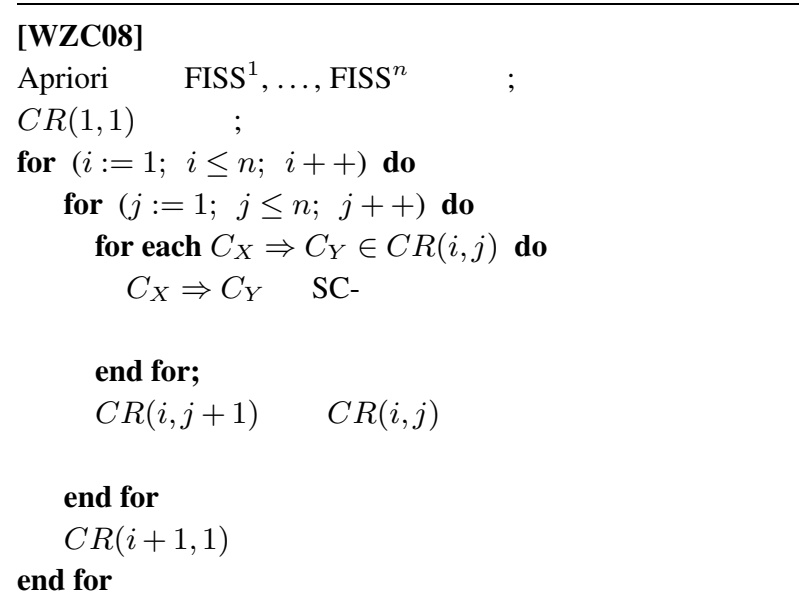

上記の負ルールの抽出部分も, Apriori スタイルのボト ムアップ (幅優先探索) 型アルゴリズムである . [WZC08]

$* 8$ 例えば, 非重複性の条件 $X \cap Y=\emptyset や ，$ 後述の conf_ub 尺 度などで枝刚する

*9 [WZC08] では最初に FISS $^{1}, \ldots$, FISS $^{n}$ をまとめて生成する ことは明記されていない . $C R(i, j)$ 関数を呼び出すたびに何度 も生成するのは，明らかに無駄と考えられるので，上記のよう な形式としてある .

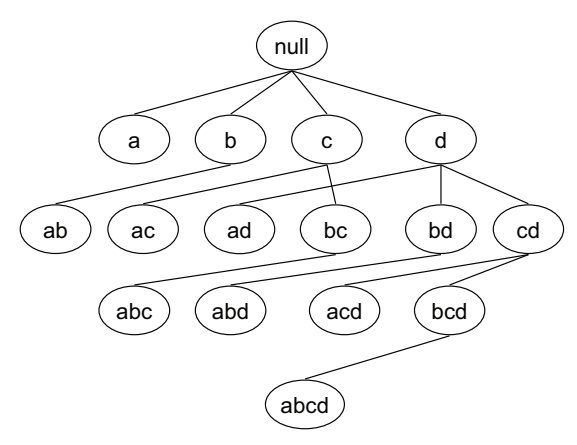

図 1 接尾木

を含めた先行研究では，どれも探索空間の効果的な枝刈 技術について殆ど何も考察されていない. 本質的に，上 のようなボトムアップ型計算の多重ループ構造では, 負 ルールの相互の関係付けか難しく, 効果的な枝刏を行う ことは極めて難しい，光こで本論文では，トップダウン (深さ優先探索) 型の負ルール抽出アルゴリズムを提案 する．

\section{$4 \cdot 2$ トップダウン型抽出アルゴリズム}

負ルールには右否定，左否定，両否定の 3 つの形があ るが, 両否定形 $\neg X \Rightarrow \neg Y$ は一般に非常に数が多い.ア イテム集合 $X$ と $Y$ の支持度は (弚れらが頻出集合であっ ても) 通常かなり小さい，光のため両否定形の支持度と 確信度は 1 に近い值となる (定義 1 を参照) ので，光の 殆どが閾值を満たすことになる．また $\neg X$ と $\neg Y$ が表す トランザクション集合は $D-D(X)$ と $D-D(Y)$ であ るが，これらの間にも統計的に有意な関係性は見出すこ とは, 通常は困難 ${ }^{* 10}$ と思われる. 以上から, 両否定形の 有用性は低く，抽出計算を行う意味はかなり小さいと考 えられる. 乥こで本論文では, 左右の否定形 $\neg X \Rightarrow Y$ と $X \Rightarrow \neg Y$ に焦点を絞り，光の効率的な抽出計算法を提案 し，理論と実際の 2 つ側面から評価を行う .

[WZC08] の負ルール抽出アルゴリズムの欠点は, 有効 な負ルールの候補の間の関連付けか弱く，探索空間の枝 刚か難しいことであった . 抽出するルールを左右の否定 形に制限することにより，トップダウン型の探索抽出が 容易になる．本論文では，接尾木 (suffix tree)を用いて， 左右の否定形ルールの間に構造を導入し, 探索空間の効 果的な枝刈技術を新たに開発する。

アイテム集合を節点とする接尾木の例を図 1 に示す． アイテムの間には適当な順序々を仮定し，アイテム集合 をアイテムの列として取り扱う. 图 1 ではアルファベッ 卜順 $a \prec b \prec c \prec d$ を仮定している . 各節点 $N_{c}$ の親は， 長さが 1 つだけ短い接尾辞 (suffix) をもつ節点 $N_{p}$ であ

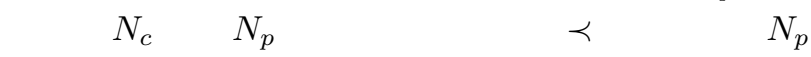
中のアイテムより前にあるものである . 兄弟関係にある

$* 10$ 通常， $D(X)$ と $D(Y)$ は $D$ よりもかなり小さい集合となる ので, $(D-D(X)) \approx(D-D(Y)) \approx D$ となっている. 


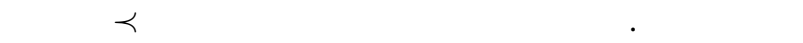
左優先深さ優先探索を行うと，節点 $N$ を訪問する時点て $N$ の部分集合は全て訪問が完了している.この特徵は定 義 4 の条件検査，特に右極小性を検査する上で都合が良 く，効果的な探索空間の枝刏に貢献*11できる .

次に負ルール $C_{X} \Rightarrow C_{Y}$ が $\mathbf{S}$-有効であることを，定義 4 の条件 (2)〜 (4) , 即ち支持度に関する 3 条件を満たす場 合と定める . 定義より $\sup (X \Rightarrow \neg Y)=\sup (\neg Y \Rightarrow X)$ が成り立つので, 以下が明らかに成り立つ．

〈命題 2〉（ $\mathbf{S}$-有効性の左右同值性） 負ルール $X \Rightarrow \neg Y$ が $\mathrm{S}$-有効であることと， $Y \Rightarrow X$ が $\mathrm{S}$-有効であること は同值である .

よって右否定形の S-有効な負ルールを全て抽出すれば， 構文的な変換処理だけで, 左否定形の S-有効なルールも 全て生成できることが分かる．本論文では SCC-有効な 負ルールの抽出を行うが，S-有効性検査は午の途中の処 理と位置付けることができる. 命題 2 は, 光の途中処理 の手間を半分にできることを示しており，大変有用であ る. 更に S-有効性の定義，命題 1 の (1) および命題 2 か ら以下が成り立つ。

[ 補題 3] ( S-有効性の単調性) 右否定形 $X \Rightarrow \neg Y$ が $\mathrm{S}$-有効ならば， $Y \subset Y^{\prime}$ なる頻出アイテム集合 $Y^{\prime}$ に関し て,$X \Rightarrow \neg Y^{\prime}$ と $\neg Y^{\prime} \Rightarrow X$ は必ず $\mathrm{S}$-有効である .

上記の性質より， $X \Rightarrow \neg Y$ が $\mathrm{S}$-有効であるならば， $Y$ のみならず，接尾木上の $Y$ の子孫節点 $Y^{\prime}$ を順次訪問し， 2 つの負ルール $X \Rightarrow \neg Y^{\prime}$ と $\neg Y^{\prime} \Rightarrow X$ の重複性と確信 度だけを検査して，SCC-有効性を確認することが可能と なる . 以上の考察を基に，本論文では以下の 2 ステップ 型の負ルールの抽出計算法を新しく提案する .

トップダウン型の負の相関ルール抽出アルゴリズム

入カ: トランザクションデータベース $D$,

支持度の閾值 $m s$, 確信度の閾値 $m c$

出力： SCC-有効な負の相関ルールの集合 . 但し $X \Rightarrow \neg Y$ の 型のルールは右極小なものに限定

ステップ 1: $D$ から $\sup (F) \geq m s$ なる頻出アイテム集合 $F$ を全て抽出し，弚の集合を FISS とする．

ステップ 2: FISS の要素を節点とする接尾木て組合せ探索を 行い, $X \in$ FISS と $Y \in$ FISS に対する負ルール $X \Rightarrow \neg Y$ の重複性，S-有効性および右極小性を検査する．検査を 合格した場合には，確信度条件 $\operatorname{conf}(X \Rightarrow \neg Y) \geq m c$ と $\operatorname{conf}(\neg Y \Rightarrow X) \geq m c$ を確認し，SCC-有効な負ルールを 抽出する.SCC-有効性を満たさない場合には，Yの子孫 節点 $T$ に対して重複性と確信度条件を順次検査する。光 の過程で右極小性等の性質を利用して探索空間を効果的 に枝刈する（詳細は次節を参照のこと）．

ステップ 1 には, 近年開発された高速抽出法 [HPY00, UKA04]を利用できる . 本論文のような枠組みは，頻出

*11ＦP-growth 法 [HPY00] も暗黙のうちに，頻出アイテム集合を 節点とする接尾木上で, 深さ優先探索を行っていることが [亀 谷他 11] で指摘されている.但し, 左優先ではなく, 右優先探 索を行っている. 光も光も FP-growth 法では極小性の概念は使 用しないので, 左優先探索の必要は無い.
アイテム集合の抽出法の将来の発展を取り込むことがで き，この意味でも有効である．また，ステップ 2 中で行 j(補題 3 に基づく) S-有効性と確信度の分離検査は，本 論文での新しい試みであり，冗長なS-有効性 (即ち支持 度) 検査を防止し，計算効率の改善が期待できる，接尾 木を用いた組合せ探索も新しい手法であり，次節で光の 詳細を述べる。

\section{$4 \cdot 3$ 接尾木を用いた SCC-有効性の高速検査}

以下にステップ 2 の詳細アルゴリズムを示す. 左否定 形の負ルールでは極小性に基づく抽出計算の効率化はで きないので，高速化のためには別の枝刈法が必要となる 幸いにも，左否定形ルールの確信度の上界を与え逆単調 性も満たす近似関数 [WZC08] か知られているので, これ を用いた分枝限定法 [亀谷他 11, MS00] を導入する.上 界を与える関数として以下の conf_ub を考える.

$$
\operatorname{conf\_ ub}(\neg X \Rightarrow Y)=\frac{\sup (Y)}{1-\sup (X)}
$$

定義より以下が明らかに成り立つ。

〈命題 3〉( 上界関数 conf_ub の左逆単調性) $X, X^{\prime}, Y$ をアイテム集合とし， $X \subset X^{\prime}$ と仮定する.このとき以 下が成り立つ。

(1) conf_ub $(\neg X \Rightarrow Y) \geq \operatorname{conf}(\neg X \Rightarrow Y)$

(2) conf_ub $(\neg X \Rightarrow Y) \geq$ conf_ub $\left(\neg X^{\prime} \Rightarrow Y\right)$

命題 3 より, conf_ub は確信度の上界をなし, 左逆単調性 が成り立つことが保証されるので, 接尾木上での $\neg Y \Rightarrow$ $X$ 型の負ルール探索の枝刈り基準として使用できる . 即 ち，閾值 $m c$ に対して conf_ub $(\neg Y \Rightarrow X)<m c$ ならば， $\neg Y \Rightarrow X$ 自身，および $Y$ の任意の子孫節点 $T$ に関する $\neg T \Rightarrow X$ は全て閾值を満たさないことが保証でき，枝刈 できる．なお [WZC08] では conf_ub の右逆単調性を利 用している . 左逆単調性の利用は本論文が初めてである . 次に幾つかの表記法を導入する.まず，Subset $(X)$ で， アイテム集合 $X$ からアイテムを 1 つ削除した部分集合の 全体，即ち $\left\{X^{\prime} \mid X^{\prime} \subset X\right.$ かつ $\left.\left|X^{\prime}\right|=|X|-1\right\}$ を表す． また child-list $(X)$ を, 節点 $X$ の全ての子節点 (アイテ 么集合) がく上の辞書順に従って並んでいるリスト $W_{1}$, $\ldots, W_{k}$ を返す関数とする.更に push-list $($ List,$S T)$ は， 与えられたリストList の各要素を逆順でスタック $S T$ に格納する関数とする.最後に，接尾木上の探索におい て，節点がチェック済みであることをラベル “CH”で示 す. また SCC-有効な負ルール $X \Rightarrow \neg Y$ の後件 $Y$ にラ ベル“OK”をマークし，更に非極小な負ルール $X \Rightarrow \neg Y$ の後件 $Y$ に対してラベル“NM”を用いる．一般に，極小 性の検査は計算量的に計算が困難なことが多い，本論文 では接尾木を用いて， $\operatorname{Subset}(X)$ の要素のラベルのチェッ クという簡便な操作 (後述の Has_No_Minimal 関数を参 照) で極小性検査を実現する .

下記の疑似コード中の縦線 “|”関数の入れ子関係を 
分かり易くするための単なる補助線である.

ステップ 2 の疑似コード :

入力: トランザクションデータベース $D$,

頻出アイテム集合の集合 FISS,

支持度の閾值 $m s$, 確信度の閾値 $m c$ ，

出力：SCC-有効な負の相関ルールの集合 . 但し右否定形の ルールは右極小なものに限定 .

変数： $S X, S Y$ : スタック; $X, Y:$ アイテム集合

$\% \%$ FISS の要素を節点とする接尾木 $T$ において, 左優先 $\% \%$ 深さ優先戦略で節点を辿る。

m1: initialize $(S X)$; \%\% スタック初期化

push-list(child-list(root), $S X$ );

m2: while $S X \neq \emptyset$ do

$X:=\operatorname{pop}(S X)$;

initialize_label; $\% \%$ 節点の前ラベルを消去

initialize $(S Y)$; \%\% スタック初期化

push-list(child-list(root), $S Y$ );

m3: $\quad$ while $S Y \neq \emptyset$ do

$Y:=\operatorname{pop}(S Y)$;

$Y$ にラベル CH をマークする;

$\mathrm{m} 4: \quad$ if $X \cap Y \neq \emptyset$ then

| do_nothing

m5: $\quad$ else if $\sup (X \Rightarrow Y)<m s$ かつ $\sup (X \Rightarrow \neg Y) \geq m s$ then

begin

m6: $\quad$ if Has_No_Minimal $(Y)$ then

$\mathrm{m} 7: \quad$ if $\operatorname{conf}(X \Rightarrow \neg Y) \geq m c$ then

| 節点 $Y$ のラベルを $\mathrm{OK}$ に変更;

output $(X \Rightarrow \neg Y) \quad \% \%$ 右極小ルール

m8: $\quad \mid$ if conf_ub $(\neg Y \Rightarrow X) \geq m c$ then

$\% \% \neg Y \Rightarrow X$ の検査と生成

m9:

if $\operatorname{conf}(\neg Y \Rightarrow X) \geq m c$ then output $(\neg Y \Rightarrow X) \quad \% \%$ 有効ルール end if;

chk_conf_LN $(X, Y)$

$\% \% Y$ の子孫節点 $T$ に対して

$\% \% \neg T \Rightarrow X$ の確信度を検査

end if

m11: $\quad$ else if conf_ub $(\neg Y \Rightarrow X) \geq m c$ then

| $\% \neg \neg \Rightarrow X$ の検査と生成

m12:

if $\operatorname{conf}(\neg Y \Rightarrow X) \geq m c$ then

output $(\neg Y \Rightarrow X) \quad \% \%$ 有効ルール

end if;

m13: $\quad$ push-list(child-list $(Y), S Y)$

| \%\% $Y$ の子節点 $T$ に対して

| $\% \% X \neg T$ および $\neg \Rightarrow X$ の

| \%\% 確信度を検査

else

m14: | $\quad$ chk_conf_RN $(X, Y)$

| $\% \%$ の子孫節点 $T$ に対して

| $\% \% \Rightarrow \neg T$ の確信度を検査

end if

else

m15:

節点 $Y$ のラベルを $\mathrm{NM}$ に変更;

$\% \%$ 以下は $\neg Y \Rightarrow X$ の検査と生成

m16: $\quad$ if conf_ub $(\neg Y \Rightarrow X) \geq m c$ then

| \%\% 以下は $\neg Y \Rightarrow X$ の検査と生成 m17: $\quad \mid$ if $\operatorname{conf}(\neg Y \Rightarrow X) \geq m c$ then output $(\neg Y \Rightarrow X) \quad \% \%$ 有効ルール

end if;

m18: $\quad$ chk_conf_LN $(X, Y)$

$\% \% Y$ の子孫節点 $T$ に対して

$\% \% \neg T \Rightarrow X$ の確信度を検査

end if

end if

end

else $\% \% X \cap Y=\emptyset$ かつ

$\% \%(\sup (X \Rightarrow Y) \geq m s$ または

$\% \% \quad \sup (X \Rightarrow \neg Y)<m s)$ の場合

m19: $\quad$ push-list(child-list $(Y), S Y)$

end if

end while;

m20: push-list(child-list $(X), S X)$

end while

$\% \% \% \% \% \% \% \% \% \% \% \% \% \% \% \%$

Has_No_Minimal $(Y)$

begin

h1: for each $Z \in \operatorname{Subset}(Y)$ do

h2: $\quad$ if $Z$ のラベルが $\mathrm{CH}$ である then

| do_nothing

else

h3: $\quad$ break \&\& return(false)

end if;

end for;

h4: $\quad$ return(True)

$\% \% \operatorname{Subset}(Y)$ 中の節点 $Z$ のラベルには

$\% \% \mathrm{OK}$ や NM は 1 つも無く，またラベルが

$\% \%$ つていない場合も無かった場合

end

$\% \% \% \% \% \% \% \% \% \% \% \% \% \% \% \%$

chk_conf_RN $(X, Y)$

begin

r1： initialize $(S T)$; \%\% スタック初期化

push-list(child-list $(Y), S T$ );

r2: while $S T \neq \emptyset$ do

$T:=\operatorname{pop}(S T)$;

$T$ にラベル CH をマークする;

r3: $\quad$ if $X \cap T \neq \emptyset$ then

| do_nothing

r4: else if Has_No_Minimal $(T)$ then

r5: $\quad$ if $\operatorname{conf}(X \Rightarrow \neg T) \geq m c$ then

節点 $T$ のラベルを $\mathrm{OK}$ に変更;

output $(X \Rightarrow \neg T) \quad \% \%$ 右極小ルール

else

r6: $\quad$ | push-list(child-list(T), $S T$ )

end if

else

r7: | 節点 $T$ のラベルを $\mathrm{NM}$ に変更

end if

end while

end

\%\%\%\%\%\%\%\%\%\%\%\%\%\%\%\%\%\%

chk_conf_LN $(X, Y)$

begin

n1： initialize $(S T)$; \%\% スタック初期化 push-list(child-list $(Y), S T)$; 


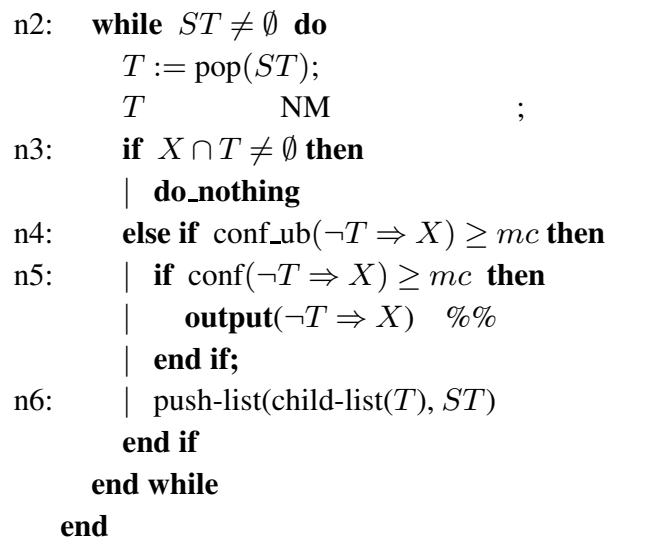

上記のアルゴリズムの完全性を示すために , まず単調 性に関する命題を以下に示す．証明は自明である。

〈命題 4〉( 重複性の単調性) $X \cap Y \neq \emptyset$ ならば, $Y \subset$ $Y^{\prime}$ である $Y^{\prime}$ に対して $X \cap Y^{\prime} \neq \emptyset$ が必ず成り立つ．

上記のアルゴリズムはまず, 行 $\mathrm{m} 4$ で $X$ と $Y$ の重複性 を検査し，重複部分があれば子節点を枝刈している.こ の枝刈は命題 4 より光の安全性が保証される . 次に m5 で $\mathrm{S}$-有効性を検査し，有効性か確認できなければ， 19 の 部分で $Y$ の子節点に探索を移行させる .ルール候補の S有効性は $\mathrm{m} 5$ で一括して検査し，弚れ以外では検査してい ないことに注意して頂きたい，確認できれば右極小性と確 信度条件の検査を行う.m6の Has_No_Minimal 関数 (後 述の補題 4 参照のこと）は， $X \Rightarrow \neg Y$ より小さい SCC有効な負ルールが存在するか否かを調べる . 存在しない 場合には $\mathrm{m} 7$ で確信度を調べている.更に $\neg Y \Rightarrow X$ の確 信度を調べる $(\mathrm{m} 9, \mathrm{~m} 12)$ が, 光の前に上界関数 conf_ub も用いて枝刚 $(\mathrm{m} 8, \mathrm{~m} 11)$ を適宜行う. $\neg Y \Rightarrow X$ に対する 左極小性は意味をなさないので, 適宜 $Y$ の子孫節点 $T$ も 調べる必要 $(\mathrm{m} 10, \mathrm{~m} 13)$ がある. $\mathrm{m} 14$ に到達した時点で は, $\mathrm{m} 11$ の conf_ub 検査で $\neg T \Rightarrow X$ の型の SCC-有効な ルールは存在しないことが判明しているので, $X \Rightarrow \neg T$ の型のルールだけを調べている .

$\mathrm{m} 15$ 以下は, m6 の Has_No_Minimal 関数が偽となっ た場合の処理である . $\mathrm{m} 10$ および $\mathrm{m} 18$ は，既に右極小 なルールが見つかっている状態なので， $Y$ の子孫節点 $T$ に対して $\neg T \Rightarrow X$ の型のルールだけを調べている.関数 chk_conf_LN は光の子孫節点を調べるので，弚れらの節 点には，最初にラベル NM をマーク (n2 部分の最後で) している．

関数 Has_No_Minimal $(Y)$ は $X \Rightarrow \neg Y$ よりも小さい SCC 有効な負ルールの存在を，各 $Z \in \operatorname{Subset}(Y)$ のラ ベルで判定している.Has_No_Minimal $(Y)$ の動作の正 当性は以下の補題から保証される．下記の条件 (1) と Has_No_Minimal 関数が偽 (false) を返すことは同値であ ることに注意して頂きたい .

[ 補題 4]（Has_No_Minimal 関数の正当性） ステップ 2で接尾木を深さ優先左優先て探索するとき，外側の while ループでの処理対象の節点を $X$ に固定して , 内側の while
表 1 実験に使用したデータセットの概要

\begin{tabular}{l|rrr}
\hline データセット & $\#$ (item) & \#(trans.) & ave(item) \\
\hline \hline T10I4D100K & 870 & 100,000 & 10.1 \\
T40I10D100K & 942 & 100,000 & 39.6 \\
mushroom & 119 & 8,124 & 23 \\
retail & 16,470 & 88,162 & 10.3 \\
kosarak & 41,270 & 990,002 & 7.1 \\
\hline
\end{tabular}

ループの接尾木探索で関数 Has_No_Minimal $(Y)$ が節点 $Y$ に対して呼ばれた時点を考える.このとき以下の $2 つ$ が同値である .

(1) ある $Z \in \operatorname{Subset}(Y)$ がラベル CH を持たない .

(2) $Y$ の真部分集合 $W(\subset Y)$ で，負ルール $X \Rightarrow \neg W$ が SCC-有効となるものが存在する .

《証明》証明は付録に示す．

補題 2,3,4 および命題 3,4 とこれまでの議論から以下 が明らかに成り立つ。

[ 定理 1]（アルゴリズムの正当性） ステップ2のアル ゴリズムは完全かつ健全である . 即ち , 右否定形のルー ルに関しては, 右極小な SCC-有効な負ルールを全て生 成し, 左否定形のルールに対しては SCC-有効な負ルー ルを全て生成し，乥れ以外のルールは生成しない。

\section{5. 実験結果と考察}

提案アルゴリズムを試験的に実装し，実証実験を行っ た結果を以下に示す. 実験には, Frequent Itemset Mining Dataset Repository [FIMI] より, ランダムデータ 2 種と 実データ 3 種のデータセットを用いた. 各データセット の詳細を表 1 に示す. \#(item) はデータセット中に含まれ るアイテムの種類数を示し, \#(trans.) はデータセット中 のトランザクションの総数, ave(item) は, 1 トランザク ション中に出現するアイテムの平均数である.

正の頻出アイテム集合の集合は, Apriori [Apriori] を 使用して抽出を行った . 最小確信度 $\mathrm{mc}$ を 0.4 に固定し， 最小支持度 ms の值を変化させて負ルールを抽出した実 験結果を表 2 に示す.

\#(FIS) と\#(FI) は光れ頻出アイテム集合と頻出ア イテムの数である. S-有効性を (m5 において) 検査する 頻出アイテム集合の対 $\langle X, Y\rangle$ を，以下では sup 検査対 と呼ぶ. 定義 4 の非重複性と右極小性の条件を用いて枝 刚りを行った場合に，sup 検査対がどの程度減少するか を削減率として示す.削減率は以下のように定める.

$$
\text { 削減率 }=1-\frac{\sup \text { 検査対の総数 }}{\text { 直積 } \mathrm{FISS}^{2} \text { の要素数 }}(\%)
$$

表 2 の右 2 列には , 接尾木の探索中に行った重複性検査 $(\mathrm{m} 4, \mathrm{r} 3, \mathrm{n} 3)$ と確信度左上界検査 $(\mathrm{m} 8, \mathrm{~m} 11, \mathrm{~m} 16, \mathrm{n} 4)$ の 総数を示している.

表 2 より, 本論文で導入した各種の枝刈りによって,多 くの場合に sup 検査対を大幅に削減でき，抽出計算の高 
速化が達成されていることが分かる.削減率が低いのは， 本実験の結果で見る限りにおいては, 頻出アイテム集合 の数か非常に小さい場合に限られている.探索時間は接 尾木上の探索時間を示しているが , (同一のデータセット においては)sup 検査対の数にほぼ比例している .

本論文では, 二つの頻出アイテム集合 $X$ と $Y$ を組合

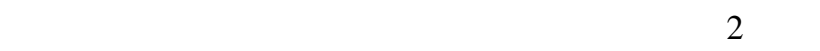
\#(FI) に対する\#(FIS) の比率と削減率との関係などを見 ると, 非重複性 $(X \cap Y=\emptyset)$ の検査が , この枠組みにお いてかなり重要な役割を果たしていることが推測される。

次に最小支持度 $\mathrm{ms}$ の值を固定し, 最小確信度 $\mathrm{mc}$ の値 を変化させて負ルール抽出実験を行った結果を表 3 に示 す. 実験に使用したデータセットは retail を用い, ms は 0.001 に固定している.最小確信度の值を变更すること によって, 左否定ルールの抽出数は変動した. 一方, 右否 定ルールの抽出数に大きな变化は見られない.

表 3 Retail セットでの最小確信度の変更に伴う抽出結果

\begin{tabular}{r|rrr|rr}
\hline $\mathrm{mc}$ & sup 検査対 & $\begin{array}{r}\text { 削減率 } \\
(\%)\end{array}$ & $\begin{array}{r}\text { 探索時間 } \\
(\mathrm{sec})\end{array}$ & $\begin{array}{r}\text { 左否定 } \\
\text { ルール }\end{array}$ & $\begin{array}{r}\text { 右否定 } \\
\text { ルール }\end{array}$ \\
\hline \hline 0.4 & $16,087,611$ & 72.07 & 415.65 & 1,977 & $15,943,237$ \\
0.5 & $16,087,611$ & 72.07 & 412.22 & 963 & $15,943,237$ \\
0.6 & $16,087,835$ & 72.07 & 414.77 & 0 & $15,943,196$ \\
0.7 & $16,088,997$ & 72.06 & 412.89 & 0 & $15,944,623$ \\
\hline
\end{tabular}

今回の実験結果では全てのデータセットにおいて，右 否定ルールは多数抽出されたが, 左否定ルールはあまり 抽出されなかった. 確信度の定義は

$$
\operatorname{conf}\left(C_{X} \Rightarrow C_{Y}\right)=\frac{\sup \left(C_{X} \Rightarrow C_{Y}\right)}{\sup \left(C_{X}\right)}
$$

であるが，ルール全体の支持度を前件の支持度で割って いる.このため $X \Rightarrow \neg Y$ のような右否定ルールでは, 前 件の支持度か閾値を僅かに上回る場合には, 確信度は大き な值 , 即ち 1 に近い值となる. 一方で, $\neg X \Rightarrow Y$ の左否定 ルールでは, 分母となる $\sup (\neg X)$ の值が大きくなり確信 度の值が小さくなる .このため今回のような結果になっ たと考えられる . mushroom データセットにおいては左 否定ルールが多く抽出されているが，これは mushroom が稠密 (dense) であることか理由として考えられる . 即 ち, mushroom ではアイテム種類数に対してトランザク ション平均長がかなり大きく, 他のデータセットと比較 して , 個々のアイテムの出現割合が非常に大きい .この ため確信度の分母の值が小さくなり，確信度が閾値を超 える場合か増えたと考えられる。

左否定ルールと右否定ルールを別々の閾值で抽出する 必要性や別の評価尺度を重複させて評価することの必要 性は, これまでの先行研究では全く指摘されていなかっ た . 本評価実験で初めて明らかになったものである .こ れらの点に関する具体的な考察は, 今後の課題としたい .
6. ま と め

負の相関ルールの完全かつ効率的な抽出は, 正のルール の抽出と比べると非常に困難である. 本論文では, 左否定 形および右否定形の負ルールを対象として，トップダウ ン型の高速抽出アルゴリズムを新しく提案した . 接尾木 を用いた重複性，支持度，極小性，左右の確信度の効率 的な検査方法と探索木の枝刘り手法を提案した . またア ルゴリズムの理論的な正当性を証明すると同時に，光の 性能について実証的な評価を行い，良好な結果を示した．

本論文では負ルールの評価尺度は支持度と確信度だけ を考えて，負ルールの高速抽出法を考えたが，これは今 後に種々の評価尺度を加えていく上での基盤となるもの である. 新しい評価尺度は, 逆単調性を満たす上界関数 が存在すれば，容易に本論文の抽出アルゴリズムに追加 可能である. これらの拡張は今後研究を進めていく予定 である . また負ルールには否定積形と否定和形が存在し ているが, 弚れ光れの応用特性などはまだ十分に研究さ れていない．これも今後の重要な研究課題と考えられる.

謝 辞

実証実験等に協力頂いた黑岩健歩氏 (山梨大学) に感謝 致します.なお本研究は一部, 平成 24 年度電気通信普及 財団研究助成および JSPS 科研費 No. 25330256 の援助を 受けたものです .

\section{$\diamond$ 参 考 文 献 $\diamond$}

[Apriori] C. Borgelt: Apriori. http://www.borgelt.net/apriori.html (2013).

[AS 94] R. Agrawal and R. Srikant: Fast Algorithm for Mining Association Rules. Proc. 20th Intl. Conf. on Very Large Data Bases, pp.487-499 (1994)

[AY 98] C. C. Aggarwal and P. S. Yu: A New Framework for Itemset Generation. Proc. 17th ACM SIGACT-SIGMOD-AIGART Symp. on Principles of Database Systems, pp.18-24 (1998)

[AZ04] M.-L. Antonie and O. R. Zaïane: Mining Positive and Negative Association Rules: An Approach for Confined Rules. Proc. 8th Euro. Conf. on Principles and Practice of Knowledge Discovery in Databases, pp.27-38 (2004)

[BMS97] S. Brin, R. Motwani and C. Silverstein: Beyond Market Baskets: Generalizing Association Rules to Correlations, Proc. 1997 ACM SIGMOD Intl. Conf. on Management of Data, pp.265-276 (1997)

[CYZC06] C. Cornelis, P. Yan, X. Zhang, and G. Chen: Mining Positive and Negative Association Rules from Large Databases. Proc. CIS 2006. Lect. Notes in Comput. Sci., Vol.4456, pp.613-618 (2006)

[FIMI] Frequent Itemset Mining Dataset Repository, URL: http://fimi.ua.ac.be/

[亀谷他 11] 亀谷由隆, 佐藤泰介: 最小サポート上昇法に基づく上位 $k$ 関連パターン発見. 人工知能学会データ指向構成マイニングと シミュレーション研究会 SIG-DOCMAS B101-4,pp.(2-24)-(2-32) (2011)

[HPY00] J. Han, J. Pei and Y. Yin: Frequent Patterns without Candidate Generation. Proc. 2000 ACM-SIGMOD Intl. Conf. on Management of Data, pp.1-12 (2000)

[MS00] S. Morishita and J. Sese: Traversing itemset lattices with statistical metric pruning. Proc. 19th ACM SIGACT-SIGMOD-AIGART Symp. on Principles of Database, pp.50-60 (2000) 
表 2 接尾木を用いたトップダウン型の負ルール抽出計算の実験結果

\begin{tabular}{|c|c|c|c|c|c|c|c|c|c|c|}
\hline $\begin{array}{l}\text { データ } \\
\text { セット }\end{array}$ & $\mathrm{ms}$ & \#(FIS) & $\overline{\#(\mathrm{FI})}$ & sup 検査対 & $\begin{array}{r}\text { 削減率 } \\
(\%)\end{array}$ & $\begin{array}{r}\text { 探索時間 } \\
(\mathrm{sec})\end{array}$ & $\begin{array}{l}\text { 左否定 } \\
\text { ルール }\end{array}$ & $\begin{array}{l}\text { 右否定 } \\
\text { ルール }\end{array}$ & $\begin{array}{r}\text { 重複性 } \\
\text { 検査 }\end{array}$ & $\begin{array}{l}\text { 確信度左 } \\
\text { 上界検査 }\end{array}$ \\
\hline \multirow{5}{*}{ T10I4D100K } & 0.01 & 385 & 375 & 144,091 & 2.79 & 24.4 & 0 & 142,358 & 407 & 142,358 \\
\hline & 0.02 & 155 & 155 & 23,870 & 0.65 & 5.82 & 0 & 22,604 & 155 & 22,604 \\
\hline & 0.03 & 60 & 60 & 3,540 & 1.67 & 1.12 & 0 & 2,967 & 60 & 2,967 \\
\hline & 0.04 & 26 & 26 & 650 & 3.85 & 0.24 & 0 & 543 & 26 & 543 \\
\hline & 0.05 & 10 & 10 & 90 & 10.0 & 0.03 & 0 & 68 & 10 & 68 \\
\hline \multirow{4}{*}{ T40I10D100K } & 0.02 & 2,293 & 610 & $1,460,052$ & 72.23 & 769.67 & 0 & $1,219,916$ & 5,360 & $1,219,116$ \\
\hline & 0.03 & 793 & 486 & 389,963 & 38.00 & 247.15 & 0 & 330,682 & 1.356 & 330,682 \\
\hline & 0.04 & 440 & 376 & 166,003 & 14.26 & 126.37 & 0 & 145,026 & 550 & 145,026 \\
\hline & 0.05 & 316 & 301 & 95,023 & 4.84 & 80.91 & 0 & 82,267 & 336 & 82,267 \\
\hline \multirow{3}{*}{ mushroom } & 0.35 & 1,189 & 24 & 37,606 & 97.34 & 6.35 & 2,734 & 2,776 & 8,148 & 1,303 \\
\hline & 0.40 & 565 & 21 & 16,858 & 94.72 & 2.56 & 1,007 & 1,007 & 3,174 & 405 \\
\hline & 0.45 & 329 & 18 & 6,556 & 93.94 & 1.44 & 231 & 231 & 1,567 & 122 \\
\hline \multirow{4}{*}{ retail } & 0.001 & 7,589 & 2,117 & $16,087,611$ & 72.07 & 415.65 & 1,997 & $15,943,237$ & 19,780 & $15,943,134$ \\
\hline & 0.002 & 2,691 & 956 & $2,578,315$ & 64.40 & 111.18 & 1,045 & $2,534,735$ & 6,310 & $2,534,713$ \\
\hline & 0.003 & 1,393 & 515 & 719,765 & 62.91 & 46.53 & 572 & 701,456 & 3,209 & 701,445 \\
\hline & 0.004 & 831 & 317 & 264,466 & 61.70 & 23.4 & 366 & 257,192 & 2,099 & 257,188 \\
\hline \multirow{5}{*}{ kosarak } & 0.01 & 383 & 54 & 21,779 & 85.15 & 68.76 & 43 & 15,025 & 1,456 & 15,021 \\
\hline & 0.02 & 121 & 27 & 3,379 & 76.92 & 19.19 & 25 & 2,275 & 205 & 2,273 \\
\hline & 0.03 & 65 & 16 & 1,086 & 74.30 & 9.15 & 13 & 638 & 195 & 635 \\
\hline & 0.04 & 42 & 13 & 561 & 68.20 & 5.61 & 15 & 331 & 109 & 329 \\
\hline & 0.05 & 33 & 10 & 324 & 70.25 & 3.88 & 8 & 161 & 86 & 160 \\
\hline
\end{tabular}

[SON98] A. Savasere, E. Omiecinski and S. Navathe: Mining for Strong Negative Associations in a Large Database of Customer Transactions. Proc. Intl. Conf. on Data Engineering, pp.494-502 (1998)

[THC02] W.-Guang Teng, M.-J. Hsieh and M.-S. Chen: On the Mining of Substitution Rules for Statistically Dependent Items. Proc. 2002 IEEE Intl. Ccnf. on Data Mining, pp.442-449 ( 2002)

[TKS02] P-N. Tan, C. Kumar and J. Srivastava: Selecting the right interestingness Measure for association patterns. Proc. 8th ACM SIGKDD Intl. Conf. on Knowledge Discovery and Data Mining, pp.32-41 (2002)

[TRLD08] D. Taniar, W. Rahayu, V. Lee and O. Daly: Exception Rules in Association Rule Mining. Applied Mathematics and Computation, Vol.205, pp.735-750 (2008)

[UKA04] T. Uno, M. Kiyomi and H. Arimura LCM ver. 2: Efficient Mining Algorithms for Frequent/Closed/Maximal Itemsets Proc. IEEE ICDM Workshop FIMI04 (2004)

[WZC08] H. Wang, X. Zhang and G. Chen: Mining a Complete Set of Both Positive and Negative Association Rules from Large Databases. Proc. 12th Pacific-Asia Conf. on Advances in knowledge discovery and data mining, pp.777-784 (2008)

[WZZ04] X. Wu, C. Zhang and S. Zhang: Efficient Mining of Both Positive and Negative Association Rules. ACM Trans. on Information Systems, Vol.22(3), pp.381-405 (2004)

[YBYZ02] X. Yuan, B. P. Buckles, Z. Yuan and J. Zhang: Mining Negative Association Rules. Proc. 7th Intl. Symp. on Computers and Communication, pp.623-629, (2002)

[ZY07] L. Zhou and S. Yau: Efficient Association Rule Mining among Both Frequent and Infrequent Items. Computers and Mathematics with Applications, Vol.54, pp.737-749 (2007)

〔担当委員 : 高間 康史〕

2013 年 12 月 25 日 受理

\section{$\diamond$ 付 録 $\diamond$}

\section{A. 補題 4 の証明}

接尾木上を深さ優先左優先で探索した場合の節点の出現順序を $Y_{1}, Y_{2}, \ldots, Y_{n}$ とする. 外側の while ループで固定した $X$ に対し て , 内側の while ループでHas_No_Minimal が複数回実行されるの で, Has_No_Minimal が検査した節点の出現順序を $Y_{i_{1}}, Y_{i_{2}}, \ldots, Y_{i_{k}}$ $\left(1 \leq i_{1}<i_{2}<\cdots<i_{k} \leq n\right)$ とする $i_{j}(j=1, \ldots k)$ に関する帰納 法で証明する。

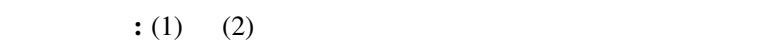
の while ループて固定された $X$ に対して， $Y_{i_{1}}$ は初めて Has_No_Minimal か呼びされた節点なので，まだラベル $\mathrm{OK} ゃ \mathrm{NM}$ は一度もマークされ ておらず, $\operatorname{Subset}\left(Y_{i_{1}}\right)$ の節点でラベルを持つ場合は, 全て CH であ る.また接尾木上の幾つかの節点は, 枝刈によって探索されないので， いずれのラベルもマークされていないが , 最初の Has_No_Minimal が 呼び出される時点までは $\mathrm{m} 4$ の非重複性検査による枝刏しか実行され

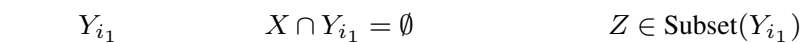
に対しても $X \cap Z=\emptyset$ が成り立ち，非重複性検査による枝刈の対 象とはならない.よって $\operatorname{Subset}\left(Y_{i_{1}}\right)$ の任意の節点はラベルを持ち， そのラベルは必ず $\mathrm{CH}$ となるので, (1) の否定が成り立つ.また初め て Has_No_Minimal か呼びされた状態であるので, $1 \leq h<i_{1}$ なる 全ての $Y_{h}$ は $\mathrm{m} 4$ もしくは $\mathrm{m} 5$ の条件検査をパスしていない.よっ て $X \Rightarrow \neg Y_{h}$ は有効なルールとはならないので, (2) の否定も明ら かに成り立つ。

帰納ステップ: $i_{1}, \ldots, i_{j}$ に対して本補題が成り立つと仮定して， $i_{j+1}$ に対しても成り立つことを証明する

まず (1) $\Rightarrow$ (2) を証明する.ある $Z_{p} \in \operatorname{Subset}\left(Y_{i_{j+1}}\right)$ がラベル $\mathrm{CH}$ を持っていない場合に， $Y_{i_{j+1}}$ の真部分集合 $W\left(\subset Y_{i_{i+1}}\right)$ で， 負ルール $X \Rightarrow \neg W$ が SCC-有効となるものが存在することを証明 する . $Z_{p}$ は接尾木上で $Y_{i_{h}}$ と $Y_{i_{h+1}}(1 \leq h \leq j)$ の間て探索され る順番にあると仮定する .

$Z_{p}$ は, $\mathrm{OK}, \mathrm{NM}$ のどちらかのラベルがマークされている場合と, 何 もマークされていない場合の 2 つに分けられる.OK がマークされて いる場合は, アルゴリズムの構成から , 負ルール $X \Rightarrow \neg Z_{p}$ が SCC有効であることが保証される．また $Z_{p}\left(=Y_{i_{h}}\right)$ は Has_No_Minimal 関数の検査をパスしているから, 帰納の仮定から， $X \Rightarrow \neg Z p$ は右 
極小であることも保証される .

$Z_{p}$ にラベル NM がマークされている場合は , アルゴリズムの構 成から， $Y_{i_{h}}$ がHas_No_Minimal 関数検査て偽となり， $Z_{p}$ は $Y_{i_{h}}$ 自 身もしくは弚の子孫節点としてマークされている.よって $Y_{i_{h}} \subset Z_{p}$ である．また帰納の仮定より， $Y_{i_{h}}$ の真部分集合 $W て ゙ X \Rightarrow \neg W$ が SCC-有効となる負ルールが存在する.$W \subset Y_{i_{h}} \subset Z_{p} \subset Y_{i_{j+1}}$ なので, (2) は明らかである .

ラベル CH は, 探索候補スタックから取り出された節点全てに必 ずマークされる (適宜, 後で OKや NM に書き換えられる).よっ て, ラベルをもたない節点 $Z_{p}$ は, 乥れ以前の枝刚によって探索さ れなかった (探索候補スタックに挿入されなかった) 節点である.光 の枝刈は重複性検査，極小性検査 Has_No_Minimal および確信度上 界 conf_ub による検査に起因する 3 種類のものがある . $Y_{i_{j+1}}$ は $X \cap Y_{i_{j+1}}=\emptyset$ なので, $Z_{p} \in \operatorname{Subset}\left(Y_{i_{j+1}}\right)$ に関しても $X \cap Z_{p}=\emptyset$ が成り立つ.よって節点 $Z_{p}$ は重複性検査による枝刈の対象とはな らないので, $Z_{p}$ がラベルを持たないならば，弚れは極小性の検査 Has_No_Minimal または確信度上界の検査 conf_ubによって枝刚さ れている. $Z_{p}$ がHas_No_Minimalによって枝刈された場合には，ア ルゴリズムの構成より， $Y_{i_{h}}$ が Has_No_Minimal 関数検査で真 (m6, r4) となり， $X \Rightarrow \neg Y_{i_{h}}$ が右極小な SCC 有効となっている. 接尾 木上で $Z_{p}$ は $Y_{i_{h}}$ の子孫節点であるので, $Y_{i_{h}} \subset Z_{p} \subset Y_{i_{j+1}}$ とな り，(2)は明らかである .

最後に $Z_{p}$ か確信度上界 conf_ub によって枝刈された場合を考える。 conf_ub は 4 か所 (m8, m11, m16, n4) で実行されるが, m11 で偽と判 断された場合は m14 で chk_conf_RN 関数か呼ばれるので, 枝刈は実 施されない.残りの $\mathrm{m} 8, \mathrm{~m} 16, \mathrm{n} 4$ で枝刏か実施されるが, $Z_{p}$ が $\mathrm{m} 8$ で 枝切されている場合は, $Y_{i_{h}}$ に対して $X \Rightarrow \neg Y_{i_{h}}$ が右極小な SCC-有 効な負ルールとなっている.m16で枝刈された場合には $Y_{i_{h}}$ が m6 の Has_No_Minimal 関数て偽と判断され, 帰納の仮定より $W \subset Y_{i_{h}}$ で $X \Rightarrow \neg W$ がSCC-有効なものが存在する. $W \subset Y_{i_{h}} \subset Z_{p} \subset Y_{i_{j+1}}$ なので, (2) は明らかである .n4 は chk_conf_LN 関数内にあるが， chk_conf_LN は m10, m18 て呼び出される.m10 て呼び出された場合 は, $Y_{i_{h}}$ が Has_No_Minimal 関数検査で真 $(\mathrm{m} 6)$ となり， $X \Rightarrow \neg Y_{i_{h}}$ が右極小な SCC 有効となっている. 接尾木上で $Z_{p}$ は $Y_{i_{h}}$ の子孫 節点であるので, $Y_{i_{h}} \subset Z_{p} \subset Y_{i_{j+1}}$ となり，(2) は明らかである. m18 で呼び出された場合は, $Y_{i_{h}}$ が Has_No_Minimal 関数検査で真 (m6) となり, 帰納の仮定より $W \subset Y_{i_{h}}$ で $X \Rightarrow \neg W$ が SCC-有効 なものが存在する. $W \subset Y_{i_{h}} \subset Z_{p} \subset Y_{i_{j+1}}$ なので, 明らかである. 次に (2) $\Rightarrow$ (1) を証明する . $Y_{i_{j+1}}$ の真部分集合 $W\left(\subset Y_{i_{j+1}}\right)$ で, 負ルール $X \Rightarrow \neg W$ が SCC-有効となるものが存在すると仮定 し，ある $Z_{p} \in \operatorname{Subset}\left(Y_{i_{j+1}}\right)$ がラベル $\mathrm{CH}$ を持たないこと，即ち $Z_{p}$ がラベル $\mathrm{OK}, \mathrm{NM}$ のどちらかがマークされているか, 全くマー クされていないことを証明する．

仮定より，右極小な負ルールが明らかに存在するので，光れを $X \Rightarrow \neg W_{\min }$ とする.よって $W_{\min } \subset W \subset Z_{p} \subset Y_{i_{j+1}}$ なる $Z_{p}$ $\left(\in \operatorname{Subset}\left(Y_{\left.i_{j+1}\right]}\right)\right)$ が存在することは明らかである . 一般性を失わ ずに, $Z_{p}$ は接尾木上で $Y_{i_{h}}$ と $Y_{i_{h+1}}(1 \leq h \leq j)$ の間で探索され る順番にあると仮定する .

$Z_{p}$ が枝刚されて全くラベルがマークされていないのであれば， (1) は自明である.よって以下では $Z_{p}$ はラベルを持つ, 即ち探索 候補スタックから取り出され (pop され) て一連の検査処理が行われ る場合を考える. $Z_{p}=W_{\min }$ の場合は，アルゴリズムの構成より， $Z_{p}=Y_{i_{h}}$ となるので, 帰納の仮定より $Z_{p}$ に対して Has_No_Minimal 関数が真になり， $Z_{p}$ にはラベル $\mathrm{OK}$ がマークされる. $Z_{p} \neq W_{\min }$ ならば, 帰納の仮定より， $Y_{i_{h}}$ に対して Has_No_Minimal 関数が偽 になるので. アルゴリズムの構成より，弚の後に $Z_{p}$ にラベル NM がマークされるのは明らかである.以上より証明が終了した．

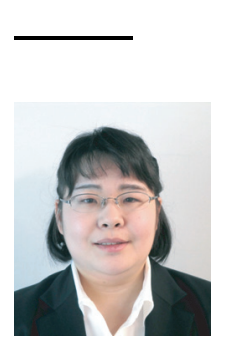

\section{者 紹}

井出 典子

2012 年山梨大学工学部コンピュータ・メディア工学科卒 業, 現在山梨大学大学院修士コンピュータ・メディア工学 専攻在在学 .データマイニング, 特に負の相関ルールの高 速マイニングの研究に従事

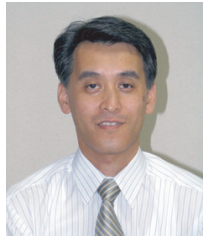

岩沼 宏治(正会員)

1985 年東北大学大学院 ·電子及通信工学専攻修士課程修 了. 同年山形大学情報工学科助手. 現在, 山梨大学大学院 医学工学総合研究部教授. 博士 (工学). 人工知能の基礎, 特に非単調論理, 定理自動証明プログラム, WEB 知的処 理,系列データマイニング等の研究と開発に従事. 1987,89, 90,91 年人工知能学会全国大会優秀論文賞 . 2004 年 FIT 優秀論文賞 . 2014 年日本ソフトウエア科学会第 3 回ソフ トウエア論文賞 .

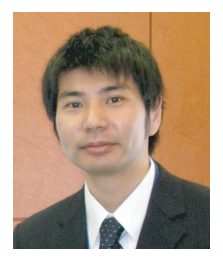

\section{山本 泰生(正会員)}

2005 年神戶大学大学院自然科学研究科電気, 電子工学修士 課程修了. 2010 年総合研究大学院大学博士課程修了. 博 \pm (情報学) . 2009 年より山梨大学大学院医学工学総合研 究部助教、帰納論理プログラミング, 仮説発見, システム 生物学, Web 知的処理などの研究に従事. 2010 年帰納論 理プログラミングに関する国際会議 (ILP2010) において最 優秀学生論文賞受賞 . 